\title{
Microbiological Quality Assessment of Laboratory Mice in Korea and Recommendations for Quality Improvement
}

\author{
Yi-Rang NA ${ }^{1)}$, Seung-Hyeok SEOK ${ }^{2)}$, Hui-Young LEE ${ }^{1)}$, Min-Won BAEK ${ }^{1)}$, Dong-Jae KIM ${ }^{1)}$, \\ Sung-Hoon PARK ${ }^{1)}$, Hyun-Kyoung LEE $^{1)}$, and Jae-Hak PARK ${ }^{1)}$ \\ ${ }^{1)}$ Department of Laboratory Animal Medicine, College of Veterinary Medicine and KRF Zoonotic Disease \\ Priority Research Institute, Seoul National University, Seoul 151-742, Republic of Korea and \\ ${ }^{2}$ Institute for Experimental Animals, College of Medicine, Seoul National University, \\ 28 Yongon-dong, Chongno-gu, Seoul 110-799, Republic of Korea
}

\begin{abstract}
Regular monitoring of commercial laboratory rodents and institutional research animal residents is essential for microbiological quality control programs. The objective of our study was to investigate the recent prevalence of infectious pathogens in laboratory mice from eight experimental animal vendors and 56 institutional animal facilities in Korea. Our investigation was conducted in 2006-2007. Specific Pathogen Free (SPF) mice from four commercial breeders were clean according to serological, bacteriological, parasitological, and histopathological examination results. However, mice from one intermediate vendor that distributed SPF animals from main commercial vendors to local districts had Syphacia obvelata and Mycoptes musculinus infections. Additionally, mice from conventional animal breeders were highly contaminated. Among the 56 institutional animal facilities, mouse hepatitis virus (MHV), Sendai virus and Mycoplasma pulmonis positive results were obtained in $23.2,8.9$, and $1.8 \%$ of animals tested, respectively. These results indicate that quarantine and eradication efforts of infectious pathogens in these facilities are sub-optimal and need to be improved. The use of commercial conventional mice for research should be eliminated and appropriate vendor selection as well as thorough quarantine before releasing animals into a facility are needed. Finally we suggest qualified veterinary experts are needed at each animal facility to ensure an adequate health surveillance program.
\end{abstract}

Key words: Korea, laboratory mice, MHV, microbiological quality, Sendai virus

\section{Introduction}

Biosecurity of laboratory animals refers to the prevention of exogenous infection, maintenance of a diseasefree status, precautions taken to detect the introduction of pathogens, and subsequent eradication efforts if pathogens are detected [3]. A comprehensive biosecurity program can prevent the introduction of new pathogens and should be conducted according to the needs of each individual facility [20].

The majority of institutions and universities have their own animal facilities for maintaining important research animal colonies. Each institution employs a manager who is responsible for the biosecurity of laboratory

(Received 3 April 2009 / Accepted 19 August 2009)

Address corresponding: J.-H. Park, Department of Laboratory Animal Medicine, College of Veterinary Medicine and KRF Zoonotic Disease Priority Research Institute, Seoul National University, Seoul 151-742, Republic of Korea 
animals in their animal facilities. Animals containing pathogens have physiological changes which could have detrimental effects not only on experiment results but also on the researchers if these diseases were transmitted to humans $[2,4,6,7,11]$. Therefore, it is the responsibility of the facility manager to ensure the microbiological quality of laboratory animals for the safety of both the animals and humans [3]. Because each animal facility imports new animals from various commercial vendors or other institutes in the case of transgenic animals, regular monitoring of general commercial production colonies and institutional rodent research animal residents is essential for the establishment of quality control programs. It is also important to establish countermeasures which must be taken when infectious diseases are identified in order to protect experimental animals which have already begun testing and to protect important transgenic animals which cannot be euthanized. Researchers should follow the facility's regulations and the facility manager should have standardized guidelines for these problems.

The Institute of Laboratory Animal Resources (ILAR) based at Seoul National University, Korea has already standardized microbiological monitoring. The monitoring results of Specific Pathogen Free (SPF) and conventional mice and rats in Korea from 2000 to 2003, based on this monitoring method, were previously published based on this monitoring method [16]. In this study, we aimed to clarify the current microbiological states of research animals in Korea in the period covering 2006 to 2007 , and to suggest some recommendations for the improvement of the quality of laboratory animals. We investigated the overall microbiological quality of labo- ratory mice from four SPF animal vendors, two intermediate vendors who distribute SPF animals to local districts and two conventional animal breeders. Additionally, 428 mice from 56 institutional animal facilities were serologically screened for Mouse Hepatitis Virus (MHV), Sendai virus, and Mycoplasma pulmonis. Finally we confirmed the current quality of laboratory mice supplied in Korea and suggest the need for appropriate vendor selection, thorough quarantine procedures and well-educated veterinary experts for maintaining overall biosecurity at each animal facility.

\section{Materials and Methods}

\section{Animals and specimen collection}

We selected a total of eight experimental animal vendors $(\mathrm{A}-\mathrm{H})$. Four were main commercial breeders that supply only SPF mice in Korea (A-D), and two were intermediate vendors that distribute SPF mice from main breeders to local districts that did not have their own breeding systems, only an animal keeping area and transportation systems (E-F). The other two were commercial breeders supplying conventional mice maintained in conventional caging without any microbiological monitoring reports $(\mathrm{G}-\mathrm{H})$. Table 1 shows the composition of SPF mice used in this study and Table 2 lists specified pathogens for each SPF mouse vendor. Mice which were 4 weeks old were excluded from serological tests due to the effect of maternal antibodies [1]. Ten ICR mice purchased from each company were euthanized by carbon dioxide overexposure after blood collection under balanced anesthesia using ketamine and xylazine. Samples of blood, liver, kidney, spleen, lung, and colon feces were

Table 1. Composition of mice from experimental animal vendors used in this study

\begin{tabular}{cccccc}
\hline Sources & Microbiological state & Group & \multicolumn{3}{c}{ No. of animals examined (age) } \\
\hline Experimental & SPF animal breeders & A & $2(4 \mathrm{w})$ & $4(10 \mathrm{w})$ & $4(6 \mathrm{~m})$ \\
animal vendors & & B & $2(4 \mathrm{w})$ & $4(10 \mathrm{w})$ & $4(6 \mathrm{~m})$ \\
& & C & $2(4 \mathrm{w})$ & $4(10 \mathrm{w})$ & $4(6 \mathrm{~m})$ \\
& & D & $2(4 \mathrm{w})$ & $4(10 \mathrm{w})$ & $4(6 \mathrm{~m})$ \\
& SPF animal intermediate vendors & E & $2(4 \mathrm{w})$ & $4(10 \mathrm{w})$ & $4(6 \mathrm{~m})$ \\
& & F & & $10(7 \mathrm{w})$ & \\
& Conventional animal breeders & G & $2(4 \mathrm{w})$ & $4(7 \mathrm{w})$ & $4(10 \mathrm{w})$ \\
& & H & $2(3 \mathrm{w})$ & $4(8 \mathrm{w})$ & $4(12 \mathrm{w})$ \\
\hline
\end{tabular}

'w' means weeks old and 'm' means months old. 
collected immediately. Collected samples underwent serological, bacteriological, parasitological, and histopathological examinations. Sera from 428 mice from 56 common animal facilities collected between 2006 and 2007 were screened for the most common laboratory mice diseases by performing serological tests for MHV, Sendai virus, and Mycoplasma pulmonis infection (Table 3) $[5,11,19]$. All animal experiments were performed under protocols approved by the Institutional Animal Care and Use Committee of Seoul National University.

Table 2. List of specified pathogens

\begin{tabular}{|c|c|c|c|c|}
\hline \multirow{2}{*}{ Specified pathogens } & \multicolumn{4}{|c|}{ SPF mice vendor } \\
\hline & A & $\mathrm{B}$ & $\mathrm{C}$ & $\mathrm{D}$ \\
\hline Rat parvoviruses (KRV, H-1, RPV) & & & $\mathrm{O}$ & \\
\hline Mouse Hepatitis Virus (MHV) & $\mathrm{O}$ & $\mathrm{C}$ & 0 & $\mathrm{C}$ \\
\hline Epizootic Diarrhea of infant Mice (EDIM) virus & & $\mathrm{C}$ & 0 & $\mathrm{O}$ \\
\hline Mouse Parvoviruses (MVM, MPV) & & $\mathrm{C}$ & 0 & $\mathrm{O}$ \\
\hline Pneumonia virus of mice (PVM) & & $\mathrm{C}$ & 0 & $\mathrm{C}$ \\
\hline Sendai virus & 0 & C & 0 & $\mathrm{O}$ \\
\hline Reovirus type 3 (REO3) & & $\mathrm{C}$ & 0 & $\mathrm{O}$ \\
\hline Mouse encephalomyelitis virus (GDVII strain) & & $\mathrm{C}$ & 0 & $\mathrm{C}$ \\
\hline Lymphocytic Choriomeningitis Virus (LCMV) & & & 0 & $\mathrm{O}$ \\
\hline Hanta virus & & & 0 & $\mathrm{C}$ \\
\hline $\mathrm{K}$ virus & & & $\mathrm{O}$ & \\
\hline Mouse Adenovirus (MadV) & & & $\mathrm{O}$ & $\mathrm{C}$ \\
\hline Ectromelia virus & 0 & & 0 & $\mathrm{C}$ \\
\hline Polioma virus & & & 0 & \\
\hline Mouse Cytomegalovirus (MCMV) & & & 0 & $\mathrm{O}$ \\
\hline Thymic virus & & & 0 & \\
\hline Lactate Dehydroganase-Elevating Virus & & & 0 & \\
\hline Salmonella sp. & 0 & & 0 & $\mathrm{C}$ \\
\hline Salmonella typhimurium & $\mathrm{O}$ & & $\mathrm{O}$ & \\
\hline Mycoplasma pulmonis (M.pul) & $\mathrm{O}$ & $\mathrm{C}$ & 0 & $\mathrm{C}$ \\
\hline Corynebacterium kutscheri & 0 & & 0 & $\mathrm{C}$ \\
\hline Clostridium piliforme (C.pil) & 0 & & 0 & $\mathrm{O}$ \\
\hline Pasteurella pneumotropica & $\mathrm{O}$ & & 0 & $\mathrm{C}$ \\
\hline Citrobacter freundii & & & 0 & \\
\hline Citrobacter rodentium & 0 & & & $\mathrm{O}$ \\
\hline Bordetella bronchiseptica & & & 0 & \\
\hline Streptococcus pneumonia & & & 0 & \\
\hline Beta-hemolytic Streptococcus & & & $\mathrm{O}$ & \\
\hline Klebsiella pneumonia & & & $\mathrm{O}$ & \\
\hline Pseudomonas aeruginosa & 0 & & $\mathrm{O}$ & $\mathrm{C}$ \\
\hline Staphylococcus aureus & & & $\mathrm{O}$ & \\
\hline Helicobacter hepaticus & & & 0 & $\mathrm{O}$ \\
\hline Cilia-associated respiratory bacillus (CARB) & & & 0 & $\mathrm{O}$ \\
\hline Streptobacillus Moniliformis & & & $\mathrm{O}$ & \\
\hline Encephalitozoon cuniculi & & & 0 & \\
\hline E. coli $015 \mathrm{a}$ & & & 0 & \\
\hline Dermatophytes & 0 & & & $\mathrm{C}$ \\
\hline Syphacia spp. & 0 & & 0 & $\mathrm{C}$ \\
\hline Aspiculuris tetraptera & 0 & & $\mathrm{O}$ & \\
\hline Intestinal protozoa & $\mathrm{O}$ & & & $\mathrm{C}$ \\
\hline
\end{tabular}


Table 3. Composition of mice from institutional animal facilities used in this study (2006-2007)

\begin{tabular}{clcc}
\hline Sources & Microbiological state & No. of facilities & No. of animals \\
\hline Common & Barrier facility & 33 & 237 \\
animal facility & Conventional facility & 23 & 191 \\
\hline \multicolumn{2}{c}{ Total } & 56 & 428 \\
\hline
\end{tabular}

\section{Serological tests}

Mouse blood was collected by the intracardiac method under deep ether anesthesia. Serum was diluted 10 times with phosphate buffered saline and further diluted 6 times with 5\% skim milk before ELISA testing. For mice from commercial vendors, the targets of the serological tests are listed in Table 4. These lists were selected based on the major infectious diseases affecting mice and recommendations from ILAR (Institute of Laboratory Animal Resources in Seoul National University) $[15,17]$. Serum ELISA was performed in 96-well polystyrene flat-bottom microtiter plates using an ELISA kit (Charles River, Wilmington, USA) following the manufacturer's recommended protocol. Mouse serum from 56 common animal facilities were screened for MHV, Sendai virus, and Mycoplasma pulmonis using ELISA plates which were made by our laboratory using previously published methods $[9,10,13]$.

\section{Respiratory airway flushing for Mycoplasma culture}

Airways were flushed 3 times from the trachea to the lung with sterilized PBS, and the recovered solution was smeared onto PPLO agar plates (Difco, Detroit, USA) containing supplement (yeast extract $0.01 \mathrm{~g}$, horse serum $20 \mathrm{ml}$, penicillin $55,000 \mathrm{U}$, thalium acetate $50 \mathrm{mg}$ in DW $30 \mathrm{ml}$ ) at a $3: 7$ ratio [8]. Plates were incubated at $37^{\circ} \mathrm{C}$ for 5 days. Any colony which formed after 5 days of incubation was confirmed by Dienes stain and Mycoplasma spp. specific PCR.

\section{Bacterial examination}

Liver, kidney, spleen, and lung samples were smeared aseptically onto 5\% sheep blood agar (Komed, SeoungNam, Korea) for bacterial examination. Plates were incubated at $37^{\circ} \mathrm{C}$ for $1-2$ days. Isolated bacteria were identified using an automatic identification apparatus (VITEK Co., Hazelwood, USA).
Table 4. Tested pathogens for SPF mice microbiological monitoring

\begin{tabular}{|c|c|}
\hline & Pathogen (total 17) \\
\hline \multirow{16}{*}{$\begin{array}{l}\text { Serological } \\
\text { test agents }\end{array}$} & Mouse cytomegalovirus (MCMV) \\
\hline & Minute virus of mice (MVM) \\
\hline & Mouse parvovirus (MPV) \\
\hline & Mouse adenovirus (MadV) \\
\hline & Polyoma virus \\
\hline & $\mathrm{K}$ virus \\
\hline & Lymphocytic choriomeningitis virus (LCMV) \\
\hline & Sendai virus \\
\hline & Pneumonia virus of mice (PVM) \\
\hline & Reovirus type 3 (REO 3) \\
\hline & Epizootic diarrhea of infant mice (EDIM) virus \\
\hline & Mouse hepatitis virus (MHV) \\
\hline & Mouse encephalomyelitis virus (GDVII stain) \\
\hline & Mycoplasma pulmonis (M.pul) \\
\hline & Clostridium piliforme (C.pil) \\
\hline & Cilia-associated respiratory bacillus (CARB) \\
\hline \multirow{15}{*}{$\begin{array}{r}\text { Bacterial } \\
\text { culture }\end{array}$} & Salmonella sp. \\
\hline & Corynebacterium kutscheri \\
\hline & Clostridium piliforme \\
\hline & Pasteurella pneumotropica \\
\hline & Citrobacter freundii \\
\hline & Citrobacter rodentium \\
\hline & Bordetella bronchiseptica \\
\hline & Streptococcus pneumonia \\
\hline & Beta-hemolytic Streptococcus \\
\hline & Klebsiella pneumonia \\
\hline & Pseudomonas aeruginosa \\
\hline & Staphylococcus aureus \\
\hline & Streptobacillus Moniliformis \\
\hline & Encephalitozoon cuniculi \\
\hline & E. coli $015 \mathrm{a}$ \\
\hline \multirow{5}{*}{$\begin{array}{l}\text { Parasites } \\
\text { examined }\end{array}$} & Dermatophytes \\
\hline & Mites (Mycoptes musculinus) \\
\hline & Syphacia spp. \\
\hline & Aspicularis tetraptera \\
\hline & Intestinal protozoa \\
\hline
\end{tabular}

\section{Parasitological tests}

Parasitological tests including the cellophane tape test, fecal floating test, and direct smear were performed to 
Table 5. Bacteriological and parasitological test results of mice from commercial breeders

\begin{tabular}{|c|c|c|c|c|c|c|}
\hline \multirow[b]{2}{*}{ Sources } & \multirow[b]{2}{*}{$\begin{array}{c}\text { Microbiological } \\
\text { state }\end{array}$} & \multirow[b]{2}{*}{ Group } & \multicolumn{4}{|c|}{ No. of positive samples/No. of samples tested } \\
\hline & & & Ectoparasites & Endoparasites & $\begin{array}{l}\text { Bacterial } \\
\text { culture }\end{array}$ & $\begin{array}{c}\text { Mycoplama spp. } \\
\text { culture from } \\
\text { endotracheal flushing }\end{array}$ \\
\hline \multirow{9}{*}{$\begin{array}{l}\text { Commercial } \\
\text { breeders }\end{array}$} & SPF & A & $0 / 10$ & $0 / 10$ & $0 / 10$ & $0 / 10$ \\
\hline & & $\mathrm{B}$ & $0 / 10$ & $0 / 10$ & $0 / 10$ & $0 / 10$ \\
\hline & & $\mathrm{C}$ & $0 / 10$ & $0 / 10$ & $0 / 10$ & $0 / 10$ \\
\hline & & D & $0 / 10$ & $0 / 10$ & $0 / 10$ & $0 / 10$ \\
\hline & & $\mathrm{E}$ & $1 / 10^{a)}$ & $0 / 10$ & $0 / 10$ & $0 / 10$ \\
\hline & & & $1 / 10^{b)}$ & & & \\
\hline & & $\mathrm{F}$ & $0 / 10$ & $0 / 10$ & $0 / 10$ & $0 / 10$ \\
\hline & Conventional & $\mathrm{G}$ & $6 / 10^{a)}$ & $0 / 10$ & $0 / 10$ & $0 / 10$ \\
\hline & & $\mathrm{H}$ & $\begin{array}{r}10 / 10^{b)} \\
2 / 10^{a)}\end{array}$ & $1 / 10^{c)}$ & $0 / 10$ & $0 / 10$ \\
\hline
\end{tabular}

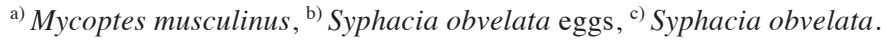

isolate ectoparasites, intestinal protozoa, and pinworms. Samples were collected from the perianal surface and bilateral wither skin regions of each mouse using Scotch cellophane tape after which the tape was pressed on the top of a glass slide. Specimens from each sample were examined microscopically for the presence of Syphacia spp. eggs around the perianal surface, and dermatophytes and mites on the wither region skins. Approximately 1 $\mathrm{g}$ of feces collected from the large intestine was mixed with water in a tube. Liquid was strained out of the solid waste using a tea strainer. A concentrated solution of sucrose (Sigma, Saint Louis, USA) was added, the sediment stirred and the tube was inverted several times. The surface layer was transferred to a microscope slide using a glass pipette. Samples were examined within one hour after the slides were made to avoid crystal formation from media evaporation. Duodenal and cecal contents were used for the direct smear test. A wet mount specimen of duodenal and cecal contents was mixed with a drop of distilled water and was examined under a microscope.

\section{Histopathological examination}

At necropsy, major organs were fixed in $10 \%$ buffered formalin for $24 \mathrm{~h}$, dehydrated in an alcohol-xylene series and embedded in paraffin wax. From each block, $2 \mu 1$ sections were prepared and stained with hematoxylin and eosin (HE), and examined microscopically.

\section{Results}

Monitoring results from the four commercial SPF animal breeders

SPF mice from four commercial breeders (A-D) were free from contamination. There were no positive results for serological tests or parasitological tests. No pathogenic agents including Mycoplasma pulmonis appeared in bacterial culture. Some positive results for nonpathogenic agents including Escherichia coli spp. and Coagulase Negative Staphylococcus in bacterial culture were considered as incidental findings and excluded from the monitoring reports. No lesions were found by histopathological examination except mild lymphocyte infiltration around the bronchus.

\section{Monitoring results from the two branch shops}

Only mice from company E showed positive results for Mycoptes musculinus and Syphacia obvelata eggs, though with a low incidence (Table 5). There were no other significant results for the serological, bacteriological, or histopathological tests.

\section{Monitoring results from the two commercial conventional animal breeders}

Monitoring results of the conventional mice from commercial breeders $(\mathrm{G}-\mathrm{H})$ indicated somewhat serious microbiological conditions (Table 5). All mice from company H were infected with Syphacia obvelata eggs. 
Table 6. Serological test results of mice from commercial breeders

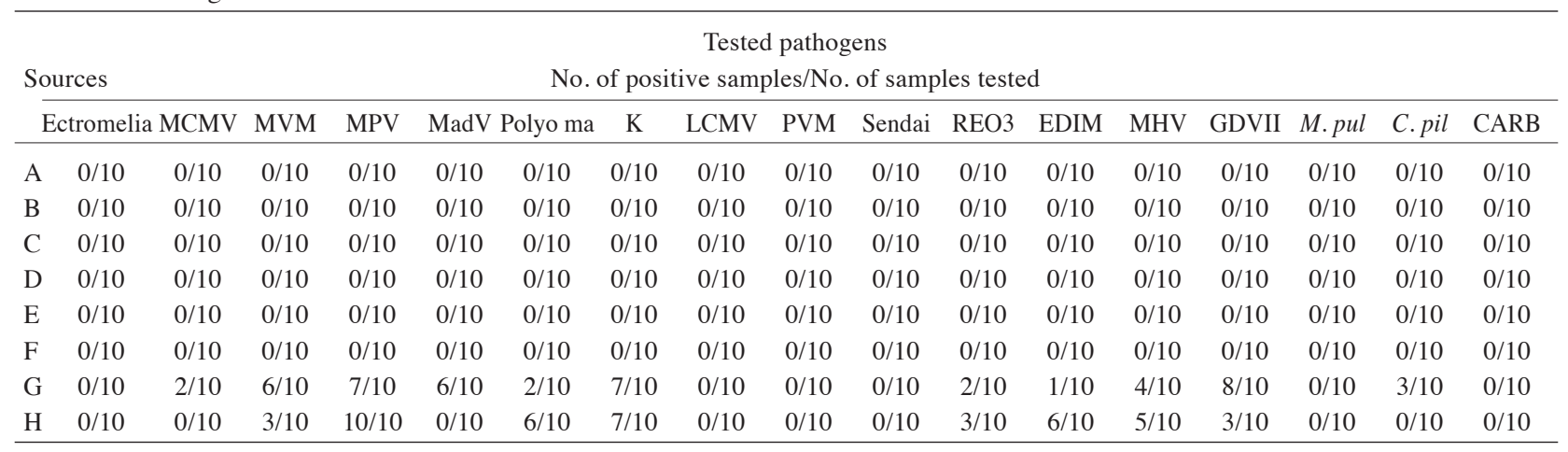

Ectromelia: Ectromelia virus, Polyoma: Polyoma virus, K: K virus, Sendai: Sendai virus, M. pul: Mycoplasma pulmonis, C. pil: Clostridium piliformis.

Table 7. Histopathological test results of mice from companies $\mathrm{G}$ and $\mathrm{H}$

\begin{tabular}{lcc}
\hline & $\mathrm{G}$ & $\mathrm{H}$ \\
\cline { 2 - 3 } & No. of positive samples/No. of samples tested \\
\hline Hepatic necrosis & $5 / 10$ & $5 / 10$ \\
Pseudobile duct proliferation & $1 / 10$ & $0 / 10$ \\
Interstitial nephritis & $2 / 10$ & $0 / 10$ \\
Myocarditis & $1 / 10$ & $0 / 10$ \\
Lymphocyte infiltration in interstitial tissue of salivary glands & $1 / 10$ & $1 / 10$ \\
Interstitial pneumonia & $2 / 10$ & $0 / 10$ \\
\hline
\end{tabular}

Additionally, Mycoptes musculinus seemed to be widespread in mice from both companies (Table 5). Serological test results indicated that these animal facilities were infected by a variety of pathogens (MCMV, MVM, MPV, MadV, Polyomavirus, K virus, REO 3, EDIM virus, MHV, Mouse encephalomyelitis virus GDVII strain) (Table 6). The ELISA test results for Clostridium piliforme were positive in three of ten mice from company $\mathrm{G}$, although the bacteriological test results were all negative. Most of these pathogens are included in ICLAS category $\mathrm{C}$ which are potential pathogens capable of causing disease in mice and affecting their physiological functions, except for MHV which is considered a category B pathogen [17]. Histopathologically, the majority of lesions presented as multifocal hepatic necrosis (50\% mice from company $\mathrm{G}, \mathrm{H}$ ). We also observed pseudobile duct proliferations, interstitial nephritis, myocarditis, and lymphocyte infiltration in the interstitial tissue of salivary glands and interstitial pneumonia (Table 7), although at low incidence.
MHV, Sendai virus, and Mycoplasma pulmonis infection of common animal facilities

Serum antibodies were screened in a total of 428 mice from 56 animal facilities for MHV, Sendai virus, and Mycoplasma pulmonis (Fig. 1). Of the tested mice, 191 mice were from conventional facilities and 237 mice were from barrier facilities. MHV was the most prevalent disease identified. It was found in 13 of $56(23.2 \%)$ mouse facilities, of which $5(38.5 \%)$ used the barrier system. Additionally, 5 (8.9\%) of the tested facilities contained mice with positive Sendai virus results, of which $4(80 \%)$ of the infected facilities were using the barrier system. A Mycoplasma pulmonis positive reaction was found in only one barrier facility.

\section{Discussion}

There are approximately 590 animal facilities in Korea including government agencies and institutions, universities and pharmaceutical companies, and five to six million laboratory animals are used for experiments 


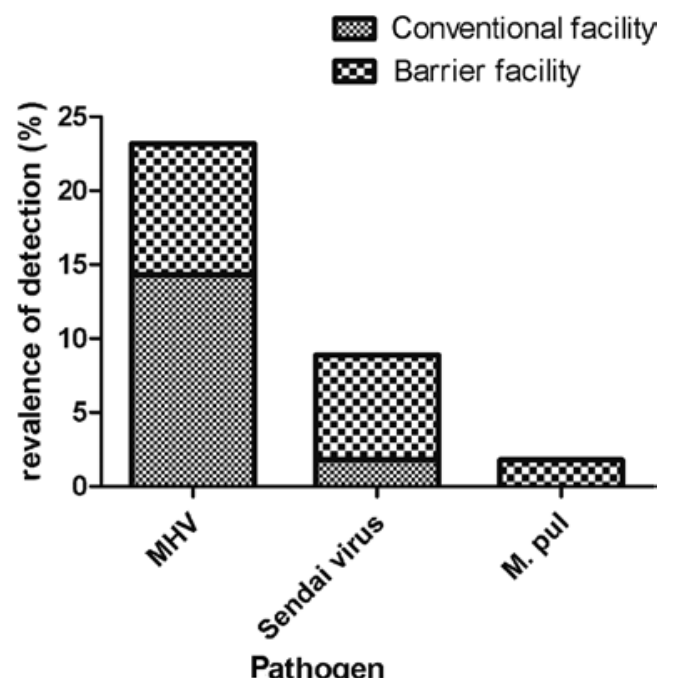

Fig. 1. MHV, Sendai virus, and Mycoplasma pulmonis (M. pul) contamination of 56 institutional animal facilities. Values shown are the prevalence in conventional and barrier facilities.

every year. To address the increasing use of experimental animals and concerns about laboratory animal ethics, the revised Animal Protection Acts was introduced on January 27, 2008 in Korea. In general, animals that are standardized as much as possible are important prerequisites for reproducible animal experiments, and animal facility managers should maintain the biosecurity of their facilities, as a first step in the production of microbiologically standardized animals for experimental use. Regular monitoring of experimental animals bred in the facilities and from commercial breeders is needed to determine the general status of current infectious diseases among mice in Korea and to establish future guidelines to improve the Korean microbiological quality control program.

Although the main experimental animal vendors have their own microbiological quality assurance system and offer monitoring reports to researchers, regular monitoring by external institutions is important to verify their cleanness [18]. We selected four major SPF mice vendors that routinely supply animals to Seoul National University. They breeds SPF mice at their own animal facilities in Korea, except one vendor whose breeding system resides in Japan. In addition, we chose two intermediate vendors that do not breeds at their own fa- cilities, but receive animals from major SPF animal vendors and keep them until distribution to a local district. The two conventional mice vendors we screened do not actually supply the animal facilities at Seoul National University because they do not clarify their microbiological status, but we assumed some researchers may still use conventional mice for pre-test or experimental method practice. As expected, all monitoring results from the four major SPF animal suppliers showed that their mice were free of contamination. However, the results of the two intermediate vendors are of some concern, as Mycoptes musculinus and Syphacia obvelata eggs infections were detected (Table 5). Syphacia obvelata is common in the caeca of wild and domestic rodents. When ingested by rodent as contaminated foods or during grooming, the Syphacia obvelata eggs hatch and the second stage larvae moves toward the caecum. Syphacia obvelata has a prepatent period (time from ingestion of infective larvae to production of eggs by mature worms) of 11-15 days [12,14]. It is therefore possible that the transportation and keeping duration might be longer than 15 days which could explain how the researchers unknowingly obtained mice infected with Syphacia obvelata and received no notification because they were given monitoring reports from the SPF breeder that did not take into account the transit time of the mice. Pinworm eggs are usually persistent environmental contaminants and stringent sanitation measures are needed to rid animal rooms of their eggs [14]. We advocate that the intermediate vendors rethink their system of animal transportation and maintenance. More importantly each animal facility manager should consider the situation of each vendors so that they can conduct more appropriate quarantine procedures, especially with regard to ectoparasites, before allowing animals into their animal rooms even though the vendor supplies only SPF animals and presents microbiological monitoring reports. Vendor selection based on regular monitoring is most important for maintaining biosecurity. We suggest information interchange between animal facilities about vendor selection criteria would strengthen appropriate quarantine procedures with respect to vendors.

Serious microbial contamination was detected in mice from the two commercial conventional animal breeders. The animals showed severe Mycoptes musculinus and 
Syphacia obvelata infections as well as positive ELISA reactions to MCMV, MVM, MPV, MadV, Polyoma virus, $\mathrm{K}$ virus, REO3, EDIM virus, MHV, mouse encephalomyelitis virus GDVII strain as well as Clostridium piliforme which causes Tyzzer's disease (Table 6). In the case of Clostridium piliforme, we obtained seropositive results from the ELISA test (vendor G) but not from the bacterial culture. These animals seem to have acquired antibodies after exposure to and clearance of Clostridium piliforme. Common contaminating agents between the two breeders were MVM, MPV, Polyoma virus, $\mathrm{K}$ virus, REO3, EDIM virus, MHV, mouse encephalomyelitis virus GDVII strain. Additionally, results from the histopathological examinations (Table 7) showing inflammation in various organs (liver, kidney, heart, salivary gland, lung) indicate that these mice should not be used as research animals. When infectious diseases has occurred in one animal facility, users of that facility cannot use other animal facilities within the campus, but a facility manager cannot recognize which researchers have been in contact with contaminated mice. This can be considered as a potential threat of infectious disease occurrence at animal facilities. Also, due to the difficulty in completely eradicating all infectious pathogens from animal facilities, researchers should not conduct any more research with experimental animals sourced from commercial conventional animal breeders.

The most prevalent pathogen was MHV (Fig. 1), a very stubborn laboratory mouse pathogen in Korea which has been present for a long time [16, 19]. Our data showed that $23.2 \%$ of tested facilities had MHV seropositive mouse, and MHV-infected mouse facilities with barrier systems account for $8.8 \%$ of the tested facilities. Compared to the monitoring data of 1999-2003 in Korea [19], which showed that $85 \%$ of conventional mouse facilities and $13.2 \%$ of barrier facilities were MHV positive, a decrease in MHV infection rates at both kinds of facility was observed in this study. MHV, classified as a category B pathogen, can be fatal to animals and is widespread in laboratory and wild mice [17]. Our results indicate that the microbiological quality of our common animal facilities, including barrier facilities, is still imperfect. Contamination of laboratory animals at these animal facilities may have resulted from the lack of a microbiological quality control specialist. Additional professional guidance is necessary to provide surveillance, to meet specific institutional needs, and to maximize the informational yield from the financial resources available for this purpose [18]. While a decrease in the infection rates of conventional animal facilities were observed in this study compared to the data from 1999 to 2003 [19], overall improvements in biosecurity including microbiological quality control and management are still needed. Although recommendations for health surveillance programs to protect and monitor the possible entry of pathogens are well documented, the actions to be taken when positive findings occur have yet to be established in institutional research centers in Korea. Therefore, we suggest the need for the appointment of qualified specialists with relevant education and experience with laboratory animals at each animal facility.

In conclusion, we have shown that SPF mice from one intermediate vendor were contaminated with ectoparasites. Mice from commercial conventional animal breeders should not be used as experimental animals. Additionally, common animal facilities in Korea are still contaminated with MHV and Sendai virus, and we suggest that qualified veterinary experts be hired by institutional animal facilities to ensure adequate biosecurity.

\section{Acknowledgments}

We thankfully acknowledge financial support from a Korean Research Foundation Grant (KRF-005-E00077) and additional financial support from the BK21 Program for Veterinary Science.

\section{References}

1. Abimiku, A. and Dolby, J. 1987. The mechanism of protection of infant mice from intestinal colonisation with Campylobacter jejuni. J. Med. Microbiol. 23: 339-344.

2. Barthold, S., Smith, A., and Povar, M. 1985. Enterotropic mouse hepatitis virus infection in nude mice. Lab. Anim. Sci. 35: 613-618.

3. Fox, J., Anderson, L., Loew, F., and Quimby, F. 2002. Laboratory Animal Medicine, second ed., Academic Press, CA.

4. Gaertner, D., Smith, A., and Jacoby, R. 1996. Efficient induction of persistent and prenatal parvovirus infection in rats. Virus Res. 44: 67-78.

5. Homberger, F. 1996. Mouse hepatitis virus. Schweiz. Arch. Tierheilkd. 138: 183-188. 
6. Homberger, F., Zhang, L., and Barthold, S. 1998. Prevalence of enterotropic and polytropic mouse hepatitis virus in enzootically infected mouse colonies. Lab. Anim. Sci. 48: $50-54$.

7. Jacoby, R., Johnson, E., Paturzo, F., and Ball-Goodrich, L. 2000. Persistent rat virus infection in smooth muscle of euthymic and athymic rats. J. Virol. 74: 11841-11848.

8. Kim, D., Park, J., Seok, S., Cho, S., Baek, M., Lee, H., Jang, D., Han, B., and Park, J. 2005. Differential identification of Mycoplasma pulmonis and Mycoplasma arthritidis using PCR-based RFLP. Exp. Anim. 54: 359-362.

9. Kim, D., Park, J., Seok, S., Cho, S., Baek, M., Lee, H., Jang, D., Yang, K., Han, B., and Park, J. 2004. Development of ELISA(Enzyme-Linked Immunosorbent assay) using LAMP of Mycoplasma pulmonis. Korean J. Lab. Anim. Sci. 20: 224-228.

10. Lee, H., Seok, S., Baek, M., Kim, D., Uhm, H., and Park, J. 2005. Enzyme-linked immunosorbent assay to detect the sendai virus infection in mice. Lab. Anim. Res. 21: 170172.

11. Lindsey, J., Boorman, G., Colins, M., Hsu, C., Van Hoosier, G., and Wagner, J. 1991. Infectious Diseases of Rats and Mice (Committee of Infectious Deseases of Mice and Rats, ed.) Naional Academic Press, Washington DC.

12. Michels, C., Goyal, P., Nieuwenhuizen, N., and Brombacher, F. 2006. Infection with Syphacia obvelata (pinworm) induces protective Th2 immune responses and influences ovalbumininduced allergic reactions. Infect. Immun. 74: 5926-5932.

13. Na, Y.R., Seok, S., Baek, M., Lee, H., Kim, D., Noh, K., Park, S., Lee, H., Dutta, N., Lee, B., and Park, J. 2006. Enzyme-linked immunorsorvent assay to detect the MHV infection in mice. Lab. Anim. Res. 22: 433-435.

14. Pritchett, K. and Johnston, N. 2002. A review of treatments for the eradication of pinworm infections from laboratory rodent colonies. Contem. Top. Lab. Anim. Sci. 41: 36-46.

15. Rehbinder, C., Baneux, P., Forbes, D., van Herck, H., Nicklas, W., Rugaya, Z., and Winkler, G. 1996. FELASA recommendations for the health monitoring of mouse, rat, hamster, gerbil, guinea pig and rabbit experimental units. Report of the Federation of European Laboratory Animal Science Associations (FELASA) Working Group on Animal Health accepted by the FELASA Board of Management, November 1995. Lab. Anim. 30: 193-208.

16. Seok, S., Cho, S., Baek, M., Lee, H., Kim, D., Yang, K., Jang, D., Han, B., Nam, K., and Park, J. 2005. Health surveillance of specific pathogen-free and conventionallyhoused mice and rats in Korea. Exp. Anim. 54: 85-92.

17. U.S. Department of Health and Human Services. 1994. Manual of Microbiologic Monitoring of Laboratory Animals, 2nd ed. (Kim, W., et al. eds.) NIH Publication, Bethesda, Maryland.

18. Weisbroth, S., Peters, R., Riley, L., and Shek, W. 1998. Microbiological assessment of laboratory rats and mice. ILAR J. 39: 272-290.

19. Won, Y., Jeong, E., Park, H., Lee, C., Nam, K., Kim, H., Hyun, B., Lee, S., and Choi, Y. 2006. Microbiological contamination of laboratory mice and rats in Korea from 1999 to 2003. Exp. Anim. 55: 11-16.

20. Workshop, F. 1994. Recommendations for the health monitoring of mouse, rat, hamster, guineapig and rabbit breeding colonies. Report of the Federation of European Laboratory Animal Science Associations (FELASA) Working Group on Animal Health accepted by the FELASA Board of Management November 1992. Lab. Anim. 28: $1-12$. 